Snežana Vukadinović

Univerzitet u Novom Sadu

Filozofski fakultet

Odsek za istoriju

snezana_vukadinovic@yahoo.com
Pregledni rad

primljeno: 20. mart 2013

prihvaćeno: 1. oktobar 2013

\title{
JEDAN KRATAK PREGLED POLITIČKIH PRILIKA RIMSKOG CARSTVA U 4. I 5. VEKU*
}

Sažetak: U drugoj polovini 4. veka Rim je ušao u poslednju fazu svog postojanja kao jedinstvene imperije i velike vojne, ekonomske i kulturne sile. Problemi koji su se godinama taložili u Rimskom carstvu kulminirali su u ovom periodu, i na kraju, nekoliko decenija kasnije, doveli i do pada tzv. Zapadnog rimskog carstva $^{1}$ i početka novog doba - nazvanog srednji vek.

Ključne reči: Rimsko carstvo, Konstancije II, Julijan, Jovijan, Valentinijan, Valens, Gracijan, Valentinijan II, Goti, Persijanci, Huni, Teodosije, Magnus Maksimus, Eugenije, Honorije, Arkadije, Stilihon, Rufin.

Posle smrti cara Konstancija II, 361. godine, na rimski presto dolaze mnogobrojni carevi, ali i neuspešni pretendenti na to zvanje, koje su izabrale i podržale vojne jedinice, sve češće sastavljene od vojnika varvarskog porekla. Tokom ovog perioda, odvija se i borba za učvršćenje hrišćanstva kao jedine državne religije, a zatim i borba među različitim hrišćanskim strujama. S druge strane, ekonomski i vojno sve slabije Rimsko carstvo pokušava da opstane pronalaženjem novih načina upravljanja - prvo određivanjem avgusta i cezara (kao cara i njegovog naslednika, ali i pomoćnika u vladanju državom), zatim sve značajnijim angažovanjem varvara u vojsci (ne više kao pomoćnih, plaćeničkih vojnih jedinica, već sve više u svojstvu federata - praktično, saveznika), da bi na kraju samo Carstvo bilo administrativno podeljeno na istočni i zapadni deo.

\footnotetext{
* Текст је настао као фазни резултат рада на пројекту Војвођански простор у контексту европске историје (број 177002) Министарства просвете, науке и технолошког развоја Републике Србије и пројекту Средюовековна насеља на тлу Војводине. Историјски процеси и догађаји (бр. 114-4512216/2011), који финансира Покрајински секретаријат за науку Владе Аутономне Покрајине Војводине.

${ }^{1}$ Kada se govori o padu Rima, pod tim se podrazumeva istorijski preokret od ogromne važnosti - prelazak iz starog u srednji vek - koji je bio praćen velikim potresima kako u moralnom i duhovnom, tako i u materijalnom životu društva. Vid. Георгије Острогорски, Историја Византије, Београд 1996, 21-87; Фјодор Успенски, Историја Византијског иарства (прев. Зоран Буљугић), Београд 2000, 3-145; Averil Cameron, Peter Garnsey, The Cambridge Ancient History, Vol. XIII, The Late Empire, A.D. 337-425, Cambridge University Press, 2008, 5-762.
} 
U Kilikiji 3. novembra 361. godine umire Konstancije $\mathrm{II}^{2}$, poslednji sin cara Konstantina Velikog ${ }^{3}$. Na rimski presto dolazi njegov rođak Julijan ${ }^{4}-$ potomak Konstantina Velikog, i poslednji preživeli potomak carske porodice. Međutim, do same smene na vlasti nije došlo prirodnim putem, već se ona odigrala kao završetak građanskih ratova i borbe za presto, koju su započeli sinovi Konstantina Velikog.

Naime, nakon što je uspeo da pobedi svoju braću i da pogubi potencijalne pretendente na carski tron (uključujući tu i Julijanovog brata, Gala ${ }^{5}$ ), Konstancije II je shvatio da ne može efikasno da upravlja ogromnim Rimskim carstvom koje se prostiralo širom evropskog kontinenta, od Britanije do Crnog mora, severnim delovima Afrike, stizalo i u Malu Aziji i delove Bliskog istoka. Stoga je odlučio da svog poslednjeg živog rođaka, Julijana uzdigne na mesto cezara 355. godine, i poveri mu upravu zapadnim delovima Carstva, prvenstveno u vidu vojnog komandanta - bez pravih administrativnih ovlašćenja. Ovaj potez nije bio plod rođačke naklonosti, već je bio iznuđen problemima sa kojima se Carstvo suočavalo - neprekidnim pljačkaškim upadima varvarskih, pre svega germanskih plemena, na zapadu, kao i Gota na istoku, odnosno dugotrajnim ratom sa Persijancima na području Bliskog istoka.

Došavši u Galiju kao vojni zapovednik, Julijan je pokazao da je vrlo talentovan i uspešan oficir, koji zna kako da motiviše i organizuje vojsku. Preuzevši komandu nad legijama, za manje od godinu dana je uspeo da nanese nekoliko teških poraza Francima i Alemanima. ${ }^{6}$ Naročito se proslavio pobedom kod Strazbura (Stratoeburgus) 357. godine i Kelna (Colonia Agrippina), tako da je do 360. godine pod rimsku vlast vratio više od četrdeset, prethodno izgubljenih, gradova, a uspeo je i da težište rata prenese na teritoriju Germana, proterujući germanska plemena i odvodeći ih u roblje. ${ }^{7} \mathrm{Za}$ vreme svojih ratova, Julijan je zarobio više od 20.000 neprijateljskih vojnika, koje je iskoristio za izgrađivanje razrušenih gradova. Obnovio je rečni saobraćaj na Rajni i snabdeo Galiju žitom dovezenim iz Britanije brodovima koje je sam izgradio. ${ }^{8}$ Time je, praktično, osigurao

\footnotetext{
${ }^{2}$ Flavius Iulius (Claudius) Constantius, kao car: Imp. Caesar Iulius Constantius Augustus - Konstancije II, vladao od 337. do 361. godine. Vid. Amm. Marc., XIV-XXI; Zosimus, II, III; Agathias, IV; Euseb., Vita Constantini, lib., IV; Eutrop., lib., X; Julian, Orat., I, II; Zonar., lib., XIII.

${ }^{3}$ Posle smrti Konstantina Velikog redosled imperatora je sledeći: od 337. do 353. godine sinovi: Konstantin II (Galija i Španija), Konstans (Italija i Afrika), Konstancije (Istok); nećaci: Dalmatije (dunavske provincije), Hanibalijan (Pont). Od 353. do 361. godine imperija je sjedinjena samo pod vlašću Konstancija. Slede: Julijan (361-363), Jovijan (363-364), Valentinijan I (363-375) na Zapadu, Valens (364-378) na Istoku, Gracijan i Valentinijan II (375-392) na Zapadu, Teodosije (379-395) na Istoku.

${ }^{4}$ Bio je jedan od potomaka Konstancija I Hlora, tačnije unuk. Vid. Julijan Imperator, Izabrani spisi (izbor i predgovor D. Kalajić, prev. sa starogrčkog i napomene Aleksandar Popović), Beograd 1987, 10-210; Dimitrij Sergejević-Merežkovskij, Julijan Apostata - Posljednji Helen na prijestolju rimskih careva, Zagreb 1913; Aleksandar Popvić, Julijan Apostata u radovima Miloša N. Đurića, Zbornik Matice srpske za klasične studije 6, Novi Sad 2004, 139-151; Edward Gibbon, The History of the Decline and Fall of the Roman Empire, New York 1969, chap. 23.; David S. Potter, The Roman Empire at Bay, AD 180-395, Routledge Hostory of the Anciente World, London - New York 2004, 499.

${ }^{5}$ Gal je imao dužnost cezara od 351. do 354. godine. Po Libaniju i Jovanu Zonari glavni krivac za Galovu smrt bio je Konstancijev zloglasni komornik i blizak savetnik, evnuh Euzebije.

${ }^{6}$ Amm. Marc., XVI, 11.

${ }^{7}$ Amm. Marc., XVI, 12,

${ }^{8}$ Ibidem.
} 
Galiju, i zaslužio veliko poštovanje lokalnog stanovništva, ali i oficira i običnih vojnika, koji su u njemu videli oličenje nekadašnjih vojnih i civilnih rimskih vrlina. Iako je javno ostao veran caru, mladi cezar je sigurno osetio da njegovo vreme dolazi i polako je počeo da se ponaša u skladu s tim. U februaru 360. godine sve je postalo jasno. U Galiju je stiglo carsko naređenje da se na Istok, u rat sa Persijom koji se odvijao sa promenljivom srećom, pošalje značajan broj vojnika iz Galije. ${ }^{9}$ Već u ovo vreme rimske legije nisu više bile sastavljene samo od profesionalnih vojnika, poreklom sa Italskog poluostrva, već su sve više to postajale jedinice čiji je etnički sastav odgovarao geografskom mestu nastanka, ili sedišta tih legija. Dakle, reč je pretežno o lokalnom galo-romanskom stanovništvu, koje se još uvek sećalo nedavnih germanskih upada, i nevoljno gledalo na carsku naredbu da se legije pošalju na Bliski istok, smatrajući, ne bez razloga, da će im tako porodice biti izložene germanskoj osveti.

Julijan je iskoristio ovu priliku da se obrati vojnicima okupljenim u predgrađu Pariza (Lutecia Parisiorum), kako bi ih naoko primirio i odobrovoljio da poslušaju cara. Međutim, ishod je bio potpuno drugačiji, mada ne i neočekivan. Galske legije su odbile poslušnost caru, i za novog avgusta izabrale Julijana. ${ }^{10}$ Ovim činom ne samo da je otpočeo novi građanski rat već je istovremeno potvrđeno da će u narednim decenijama vojska biti jedini faktor za izbor novih careva. Senat i Rimski narod više nisu odlučivali o tome ko će ih predvoditi.

Julijan je delovao brzo i odlučno, i serijom smelih poteza prvo dodatno obezbedio Galiju, porazivši još neka germanska plemena, a zatim se u proleće 361. godine uputio na Istok. Iznenadnim akcijama, bez većih sukoba sa vojskom lojalnom Konstanciju II, Julijan je stigao na granicu Mezije i Trakije, i odredio Niš (Naisus) kao bazu svojih delovanja. Tu je odlučio da sačeka carsku vojsku, koja mu je pošla u susret iz Male Azije. Međutim, do velikog sukoba nije došlo, jer je Konstancije II umro, a pred smrt imenovao upravo Julijana za svog naslednika. ${ }^{11}$

Car Julijan Flavije Klaudije, poznat kao Julijan Apostata, ali i Julijan Filozof, bio je jedan od dvojice sinova Konstancija Gala koje je Konstantin II poštedeo smrti tokom čistke u svojoj porodici. Zajedno sa svojim bratom rastao je u maloazijskim manastirima gde je, praktično u pritvoru, stekao zavidno obrazovanje (jedan od učitelja mu je bio i Euzebije, kasnije nikomedijski biskup). Međutim, njegovo obrazovanje je produbljeno boravkom u Atini od 355. godine, gde upoznaje grčku kulturu i filozofiju i ubrzo postaje neoplatoničar po ubeđenju. Smatra se da je pod uticajem svojih prijatelja, ali i učitelja, Mardonija i Maksima, prihvatio i grčku pagansku religiju. Svoje otpadništvo od hrišćanske vere Julijan nije javno ispoljavao sve dok, nakon kratkog građanskog rata i smrti Konstancija II, nije dobio titulu avgusta. Sam Julijan uradio je nešto što ga je jasno odvojilo od prethodnog cara. Javno je obznanio svoja religijska i filozofska uverenja, i odbacio hrišćanstvo kao državnu religiju Rima. ${ }^{12}$ Time je ovaj sukob dobio i verska

\footnotetext{
${ }^{9}$ Amm. Marc., XX, 4.

${ }^{10}$ Amm. Marc., XX, 8.

${ }^{11}$ Amm. Marc., XXI, 12.

${ }^{12}$ U Atini se Julijan upoznao sa stubovima opadajuće antičke kulture, a veliki žrec eleusinskih misterija dodelio mu je zvanje najvećeg stepena, što je tada značilo potpuni raskid sa hrišćanstvom i vraćanje ,otačkoj religiji“, kako se često izražavao Julijan. Vid. David Hunt, The Cambridge Ancient History, Vol. XIII, The Late Empire,
} 
obeležja. Ubeđen da su mu stari bogovi podarili pobedu i dali pravo da vlada Rimom, doneo je edikt o verskoj toleranciji kojim je ponovo izjednačio sve religije u Rimu. To se nije svidelo hrišćanima koji su se uplašili novih progona, a još više su bili uvređeni kad je Julijan zabranio da hrišćani budu predavači retorike i filozofije i dozvolio Jevrejima da obnove svoj Veliki hram u Jerusalimu. Tim svojim delima u očima hrišćana bio je jedan od najozloglašenijih rimskih careva, iako, kao neki njegovi prethodnici, nikada nije vršio progone. Iako su saradnici pokušali da ga odgovore od velikog pohoda na Persiju, Julijan je smatrao da će mu pobeda na Istoku doneti u očima naroda isti status, kao onaj koji je uživao u Galiji. ${ }^{13}$ Ipak, što zbog objektivnih, što zbog subjektivnih razloga, pohod na persijsku prestonicu Ktesifon je vrlo brzo ušao u krizu koja je kulminirala carevim ranjavanjem i smrću u bici, 26. juna 363. godine. ${ }^{14}$ Time je vojska ostala obezglavljena usred neprijateljske teritorije. Oficiri su brzo reagovali, i uprkos nesuglasicama, za novog naslednika proglašen je car Jovijan. ${ }^{15}$

Bio je to jedini rimski car koji je rođen u Beogradu (Singidunum) i vladao je svega osam meseci. Jovijan se odmah suočio sa teškim zadatkom izvlačenja vojske iz neprijateljskog okruženja. Zbog načina na koji je to uradio, sklopivši prilično nepovoljan mir sa Persijom, mnogi su mu zamerili, ali je time ipak uspeo da izvrši svoj primarni zadatak. Vratio je vojsku u Antiohiju, a zatim se uputio ka Konstantinopolju. Međutim, u prestonicu nije nikad stigao. Umro je u toku noći, 17. februar 363. godine, u svom šatoru verovatno usled isparenja ugljen-monoksida. U svojoj kratkoj vladavini ostao je upamćen po sramnom miru sa Persijom, ali i po tome što se, za razliku od Julijana, potrudio da vrati hrišćanstvo na mesto državne religije - mada nije ulazio u otvoreni sukob sa pojedinim paganskim kultovima. ${ }^{16}$

Posle Jovijanove smrti vojska je opet bila ta koja je odlučivala o novom caru. Iako podeljena na galsko-germanske oficire sa zapada, i gotsko-istočnjačke oficire sa istoka, vojna klika je uspela da se dogovori oko jednog imena - Flavije Valentinijan. ${ }^{17}$ Međutim, ovaj put su vojnici insistirali na tome da odmah izaberu i drugog kandidata, koji bi praktično imao ista ovlašćenja i bio carev pomoćnik i zamenik. Više se nije radilo o tituli cezara, već je vojska, poučena persijskim iskustvom i nedavnom Jovijanovom smrću, zahtevala da Valentinijan dobije savladara. Valentinijan je iskoristio priliku da na to mesto dovede svog brata - Valensa. ${ }^{18}$ Dogovori i reorganizacija carstva su trajali sve do 366.

A.D. 337-425, Cambridge University Press, 2008: 44-73; Sozomenus, Historia ecclesiastica, 6.2.; Libanius, Oration 18, 306; Amm. Marc., XXII, 5; XXIII, 2.5; XXV, 5.1.

${ }^{13}$ Amm. Marc., XXII, 12.

${ }^{14}$ Amm. Marc., XXV, 3, 15 .

${ }^{15}$ Amm. Marc., XXV, 5-7; Edward Gibbon 1969: 517-529; Amm. Marc., XXV, 5-7.

${ }^{16}$ Po istoričaru crkve Sokratu Sholastiku, koji je pisao u prvoj polovini 5. veka, Jovijan je svojevremeno odbio Julijanovo naređenje da prinese žrtvu paganskim bogovima i radije je izabrao napuštanje službe. Tek kada je Julijan krenuo u Persiju, Jovijan je ponovo primljen u vojsku. Pozniji hrišćanski autori (Sozomen, Jovan Malala, Jovan Zonara) pišu da je Jovijan kao uslov prihvatanja carskog trona zatražio od prisutnih vojnika i senatora da se izjasne kao hrišćani. Iako su ove anegdote svakako apokrifne, one dobro prikazuju raskid sa Julijanovim pokušajem obnove paganstva.

17 Amm. Marc., XXVI-XXX; Zonaras, Extracts of History XIII. 8.5-13; Eutropius, Historiae Romanae Breviarium X.11-12; Aurelius Victor, Epitome de Caesaribus, 45.9.

${ }^{18}$ Amm. Marc., XXVI, 4; Edward Gibbon 1969, 66. 
godine, kada su dva brata i imperatora konačno podelila provincije, legije i administraciju. Valentinijan je preuzeo zapadni deo Carstva i prestonicu prebacio u Milano (Mediolanum), dok je Valens ostao na istoku, vladajući iz Konstantinopolja. Oba cara, iako nisu pripadali istim verskim učenjima, bili su hrišćani, tako da je za vreme njihove vladavine pozicija hrišćanstva dodatno ojačala.

Uprkos reorganizaciji i pokušajima konsolidacije, Rimsko carstvo je nastavilo da tone na istorijskoj pozornici. Već 365. Alemani nastavljaju sa snažnim upadima u Galiju, a javlja se i prvi uzurpator prestola - Prokopije. ${ }^{19}$ Valentinijan odlazi u Galiju i tokom dvogodišnje kampanje uspeva da obuzda germanska plemena, ali se 367 . godine ozbiljno razboljeva. To ga dovodi u situaciju da 27. avgusta 367. godine pred okupljenim legijama proglasi svog osmogodišnjeg sina, Gracijana, ${ }^{20}$ za novog avgusta. Iako ovo predstavlja presedan, zbog toga što je novi car tako mlad, legije su Gracijana prihvatile. Ali, Valentinijan se ipak oporavio i nastavio operacije u Galiji i Germaniji, sve do 374. godine, kada je sa Alemanima potpisan mir. Uprkos uspesima u ovom ratu, Valentinijan je postao svestan da Rim više nema snage za dalja osvajanja, pa čak ni za odbranu svih granica. Neprekidni sukobi sa varvarima crpeli su ekonomsku snagu Rima, ali i smanjivali broj potencijalnih vojnika. Zato je 374. godine sklopljen mir sa Alemanima, jer se u provinciji Iliriji pojavio novi problem. Kvadi i Sarmati, varvarska plemena, ugrozili su Panoniju i Meziju, ali su uz velike napore odbijeni. Valentinijan je uzvratio 375. godine i praktično uništio čitavo pleme Kvadra, u znak odmazde za prethodne napade. ${ }^{21}$ Ali, po povratku sa ovog pohoda, ponovo se razboleo, i umro je 17 . novembra 375 . godine. ${ }^{22}$ Pošto je u tom momentu Gracijan bio u Galiji, panonske legije su odlučile da na Valentinijanovo mesto postave novog cara, njegovog mlađeg sina, četvorogodišnjeg Valentinijana II. $^{23}$ Ova odluka je razbesnela i Gracijana i Valensa, jer su sada, praktično, postojala tri cara, ali je i pokazala ko ima stvarnu moć prilikom izbora novih careva. Zato su carevi postali sumnjičavi prema iskusnim oficirima koji su se pokazali kao vešti generali na bojnim poljima. Dokaz za to je i sudbina Flavija Teodosija ${ }^{24}$ koji je za vreme Valentinijana I uspeo da uguši ozbiljne pobune Pikta i Sarmata u Britaniji 367. godine, kao i da tamo porazi potencijalnog uzurpatora, Valentinijana. Isti oficir je 373. godine ugušio i novu pobunu, ovaj put u Africi, i pobedio još jednog uzurpatora na Valentinijanov presto Firmusa. Međutim, Teodosijeva nagrada za lojalnost, pokazanu hrabrost i veštinu prilikom vođenja ovih vojnih pohoda bila je kobna za njega. Nedugo posle Valentinijanove smrti, proglašen je krivim za zaveru protiv novog cara i ubijen. ${ }^{25}$

Krajem 4. veka u Rimskoj imperiji zapaža se još jedna pojava koja je u daljoj istorijskoj evoluciji imala najveći značaj posle hrišćanstva. Reč je o novim narodima koji

\footnotetext{
${ }^{19}$ Amm. Marc., XXXI, 5-10.

${ }^{20}$ Amm. Marc., XXVII, 6; Symmachus, Relationes, 1-3; Ambrosius, Epistules, 17-18.

${ }^{21}$ Amm. Marc., XXVII, 7-10; XXIX, 3; John Curran, The Cambridge Ancient History, Vol. XIII, The Late Empire, A.D. 337-425, Cambridge University Press, 2008, 80-87.

${ }^{22}$ Amm. Marc., XXX, 6.

${ }^{23}$ Amm. Marc., XXX, 10; Eunapis, Historia nova, IV, 53.

${ }^{24}$ Otac budućeg cara Teodosija. Vid. R. C. Blockley, The Cambridge Ancient History, Vol. XIII, The Late Empire, A. D. 337-425, Cambridge University Press, 2008, 111-135.

${ }^{25}$ Ibidem.
} 
su, čas sa oružjem u rukama, čas kao mirni kolonisti, naseljavali rimske provincije. Najjači nosioci seobe naroda bili su Goti. ${ }^{26}$ Iako, prvobitno, zaokupljen idejom o novom pohodu na Persiju i bogatstvom Mesopotamije, Valens se vrlo brzo suočio sa ozbiljnom pretnjom od gotske invazije na Trakiju. Njegove poteze budno je pratio Prokopije, Julijanov rođak, još jedan pretendent na carski presto, koji je već bio iskusan vojni komandant u Maloj Aziji. Iskoristivši carevo odsustvo iz Konstantinopolja, zbog okupljanja legija sa istoka, Prokopije je preuzeo vlast u Konstantinopolju, a zatim i pridobio legije u Trakiji, pa čak i Gote, da mu pomognu u građanskom ratu. Ilirija je ostala verna Valensu, kao i bliskoistočne provincije, ali car još uvek nije bio spreman za sukobe sa uzurpatorom, Gotima i Persijom. Zapovednici legija u Maloj Aziji prelazili su s jedne na drugu stranu, pa je tako i ratna sreća bila čas na strani uzurpatora Prokopija, a čas na strani cara Valensa. Ipak, 366. godine, Prokopija su izdali oficiri i predali ga Valensu, koji ga je pogubio. Želeći da kazni i Gote zbog pomoći Prokopiju, a i zbog pretnje Trakiji, sledeće tri godine Valens je proveo ratujući na području Trakije i Karpata. Ipak, tek 369. godine je uspeo da nanese značajne poraze Gotima, posle čega su oni zatražili mir, na koji je Valens pristao. Razlog za mir sa Gotima, pored činjenice da je bio povoljan za Rimsko carstvo, treba tražiti i u obnavljanju nesuglasica sa Persijom. Rimljani nisu zaboravili po njih sramni mir, prinudno sklopljen između Jovijana i persijskog cara Šaprona II, te su čekali priliku da povrate svoje pozicije na istoku. Posle serije ratnih sukoba između Jermenije i Persije, prvo su Sasanidi uspeli da steknu prevlast nad Jermenijom do 370. da bi od te godine, pa do 373. ratna sreća prešla na stranu Jermena i Rima (koji je podržao jermenskog kralja Papa). Posle niza sukoba, potpisan je novi mir 373. godine, ovaj put znatno povoljniji za Rim, što se može smatrati Valensovim uspehom. ${ }^{27}$

Posle smrti Valentinijana i činjenice da su na zapadu sada postojala dva avgusta Gracijan i Valentinijan II, Valens je razmišljao o pohodu na Zapad. Ipak, pobune u Maloj Aziji i na Bliskom istoku, kao i obnovljene nesuglasice sa Persijom, sprečile su ga u ovome. Iako je uspeo donekle da sredi stanje na Istoku, Valens se vrlo brzo suočio sa novim problemom u Trakiji - naseljavanjem Gota. Naime, 375. godine Huni ${ }^{28}$ su masovno prodrli u Evropu, uništavajući jedna za drugim plemena koja su se nalazila na obalama Crnog mora. To je podstaklo tzv. Veliku seobu naroda, koja će praktično biti konačni udarac Rimskom carstvu, i stotinu godina kasnije dovesti do pada Zapadnog rimskog

\footnotetext{
${ }^{26}$ Goti su krajem 2. veka (160-170), iz svoje postojbine kraj Baltičkog mora krenuli prema jugu i ovde izazvali pomeranje naroda Istočne Evrope. Kretanje Gota sa severa prema jugu trajalo je najmanje trideset godina. Početkom 3. veka oni su već zauzimali jugoistočnu Evropu od Dunava do Dona. Reka Dnjestar je tada delila Gote na dve grupe - na istočne i zapadne. Nije poznato da li su Goti još u svojoj postojbini bili podeljeni, ili je do podela među njima došlo kasnije, na rimskoj granici. U svakom slučaju, u 3. veku Goti se dele na Ostrogote (istočne Gote) i Vizigote (zapadne Gote). Prvi su sebe na svom jeziku nazivali još i Gejtunzima i njima je vladao rod Amala, a drugi su se nazivali Tervinzima i njima je upravljao rod Balta. Vid. Успенски, Историја Византијског изарства, 120; Amm. Marc., XXXI, 4.

${ }^{27}$ John Curran, $C A H, 78-108$.

${ }^{28}$ Huni su dugo smatrani narodom mongolskog porekla i njihova istorija je zasnivana na izvorima kineskih pisaca. Danas vlada mišljenje da je to narod mešovitog porekla. Ovi nomadi su zauzeli ravnice između Volge i Urala početkom 1. veka. Južna horda poznata je pod imenom belih Huna i pominje se kod persijskih istoričara, a severna horda ili crni Huni, vladala je na Uralu. Upor.: Peter Heather, The Cambridge Ancient History, Vol. XIII, The Late Empire, A.D. 337-425, Cambridge University Press, 2008, 487-507; Amm. Marc., XXXI, 2-3.
} 
carstva.

Pred Hunima, i njihovim srodnicima Alanima, počeli su prvo da se povlače Ostrogoti i Vizigoti. Mase varvara su došle do Dunava i zahtevale od Valensa da ih pusti da nasele Trakiju. Zauzvrat su obećavali da će dati regrute u rimsku vojsku, kao i da će ekonomski samim svojim prisustvom ojačati ovaj deo carstva. Goti su uputili molbu ${ }^{29}$ Valensu, koji se nalazio u Antiohiji, a on je odobrio prelazak Dunava samo jednom plemenu. Međutim, pritisak drugih plemena, kao i loše ponašanje lokalnih rimskih zapovednika, doveli su do toga da i ostatak Gota pređe Dunav. Tačan broj pridošlica se ne zna (procene se kreću od 30.000 do 200.000), ali je do sukoba sa Rimljanima došlo gotovo momentalno. Sukobi većeg i manjeg intenziteta su nastavljeni i sledeće dve godine, a Gotima su u pomoć priskočili i Huni i Alani, privučeni mogućnošću za bogatim plenom. Pritisak varvara je bio toliki da je Rimsko carstvo moralo da odgovori opštom mobilizacijom trupa, i sa istoka, i sa zapada. Valens je 378. godine odlučio da preduzme odlučujući napad i primiri Gote. Ohrabren Gracijanovim napretkom sa zapada, ali istovremeno i pod pritiskom da zadrži svoj autoritet, Valens je naredio da se započne bitka nedaleko od Hadrijanopolja (današnjeg Jedrena). Zavaran pogrešnim procenama car je naredio opšti napad na neprijateljski logor, ne znajući da Goti očekuju velika pojačanja. Bitka se odigrala 9. avgusta 378. godine, a njen rezultat je bio poražavajući za Rimsko carstvo. Pored gubitaka koji su procenjeni na preko 30. 000 vojnika (neki izvori tvrde i 50 000) poginuo je i sam car Valens. Istoričar Amijan Marcelin smatra ovaj poraz najvećim u rimskoj istoriji posle poraza od Hanibala, kod Kane. ${ }^{30}$

Celo poluostrvo, sve do samih zidina Konstantinopolja, bilo je prepušteno Gotima i oni su se pljačkom i pustošenjem svetili Rimljanima. Zapadni imperator Gracijan, obavešten o opasnosti na Balkanskom poluostvu, poslao je Valensu u pomoć mornaricu i vojsku. Ali kad je čuo za tragičan ishod bitke kod Hadrijanopolja, Gracijan se više nije usuđivao da ulazi u otvoreni sukob sa Gotima. Stupivši u pregovore sa nekim varvarskim vođama, on je ubedio Ostrogote da se nasele u Južnoj Panoniji, a na Valensovo mesto 19. januara 379. godine postavio je i proglasio za avgusta Flavija Teodosija, ${ }^{31}$ sina $^{2}$ pogubljenog istoimenog Valentinijanovog generala. ${ }^{32}$

Teodosije i Gracijan, nemoćni da se ponovo direktno suoče sa Gotima, preduzeli su niz mera koje su imale za cilj da otupe oštricu varvarskih napada. Naruku im je išlo i to što su Goti i njihovi saveznici predstavljali skup plemena bez jedinstvne organizacije, tako da su se nakon Hadrijanopolja oni rasuli u niz plemena koja su nastavila da pljačkaju Trakiju, Makedoniju, Dakiju, Iliriju i Meziju. Rimljani su odgovorili tako što su naneli niz poraza manjim grupama, dok su neka plemena uspeli da potkupe i učine ih federatima -

\footnotetext{
${ }^{29}$ Ovo se događalo 376. godine. Imperator Valens, koji se tada nalazio u azijskim provincijama zbog rata sa Persijancima, dao je saglasnost da se Goti prime u rimske oblasti s pravom federata. Naseljavanje Gota trebalo je da se obavlja po određenom redu i na utvrđen način. Ali, taj red je bio narušen još pre izdavanja dozvole: gomile varvara su plivajući prelazile na rimsku obalu, gde su ih oružjem primoravali da se vraćaju natrag. To su bili uzroci zbog kojih su izbijali sukobi koji su dovodili do krvavih borbi. Opširnije vid. Peter Heather, CAH, 487-490. Amm. Marc., XXXI, 4-6.

${ }^{30}$ Amm. Marc., XXXI, 13,19.

${ }^{31}$ Hartmur Leppin, Teodosius der Grosse, Wissenschafliche Buchgesellschaft, Darmstand 2003.

${ }^{32}$ R. C. Blockley, CAH, 111-135.
} 
vojnim saveznicima, koji su služili u rimskoj vojsci, ali pod zapovedništvom svojih plemenskih vođa. Sukobi su nastavljeni sve do 382. godine, a završeni su mirom koji je Teodosije sklopio sa Gotima. Po uslovima ovog mira, Goti su naseljeni duž obala Dunava, i dublje u okviru granica Rimskog carstva dobili su zemlju i određena prava, a zauzvrat je trebalo da daju regrute u više nego desetkovanu rimsku vojsku. Iako su i ranije varvari primani na teritoriju Carstva, ovo je praktično prvi put da su plemena zadržala svoju vojnu i političku strukturu i tako formalno postala samostalne nacije na teritoriji Rima. Ovaj privremeni uspeh u rešavanju gotskog problema, omogućio je Teodosiju da se pozabavi i drugim pitanjima vezanim za uređenje istočnog dela Carstva. On se zalagao za ortodoksno hrišćanstvo, koje je Petar doneo u Rim. Bio je protivnik arijanstva, koje je imalo snažno uporište u istočnom delu Carstva. ${ }^{33}$

Iako je Gracijan od 375. godine morao da, makar formalno, deli vlast sa svojim polubratom Valentinijanom II, on je zapravo bio pravi vladar zapadnog dela Rimskog carstva, a nakratko - od Valensove smrti do Teodosijevog izbora, čak i jedini imperator. Stalni sukobi sa varvarima, od Britanije do Trakije, koji su pratili njegovu vladavinu, izazivali su nezadovoljstvo kod pojedinih delova vojske, a tome je doprineo i sam Gracijan nekim svojim osobinama. Stoga je 383. godine vojska iz Britanije proglasila Magnusa Maksimusa ${ }^{34}$ za novog avgusta. Ovaj izbor su podržale i legije sastavljene od Germana naseljenih u Galiji, ali su osporile galo-romanske legije, ostavši verne Gracijanu. Do sukoba je došlo nedaleko od Pariza, a rezultat je bio Gracijanov poraz i pokušaj bekstva. Ipak, uhvaćen je nedaleko od današnjeg Liona (Lugdunum), i pogubljen 23. avgusta 383 . godine. ${ }^{35}$

Preuzevši Gracijanovu titulu, Maksimus je izrazio želju da se pomiri sa Valentinijanom II i Teodosijem, pod uslovom da ga priznaju kao novog avgusta. Svesni da ga ne mogu vojno poraziti, obojica su na to pristali, pa je 384. godine on i zvanično priznat za cara. Međutim, mir u Carstvu nije dugo trajao. Već 386. godine Maksimus je preduzeo pohod protiv Valentinijana II, iskoristivši Teodosijevu zaokupljenost sklapanjem trajnijeg mira sa Persijom (što je i uspeo iste godine, podelivši Jermeniju sa Persijancima). Valentinijan II je pobegao u Solun, pod Teodosijevu zaštitu, a Maksimus, bez većih borbi ušao u Milano i 388. godine preuzeo vlast nad celim zapadnim delom Carstva. Teodosije nije želeo da čeka na sledeći Maksimusov potez, te je i sam preduzeo ofanzivne akcije, donekle iznenadivši Maksimusa, koji je zarobljen u Akvileji. Suđeno mu je za zločine protiv Rima, i na kraju je pogubljen, 28. avgusta 388. godine. Teodosije je na presto vratio Valentinijana II, ali je sada samo on kontrolisao celo Carstvo. To mu je omogućilo nastavak sprovođenja religijskih mera koje je započeo, tako da je 391. godine proglasio da su paganski kultovi zabranjeni na celoj teritoriji Carstva. Svi hramovi, sem hrišćanskih, pozatvarani su ili srušeni, a druge vere proglašene su nelegalnim. ${ }^{36}$

\footnotetext{
${ }^{33}$ Ibidem.

${ }^{34}$ Socrates Scholasticus, Historia Ecclesiastica, V, 8, 11; Sozomen, Historia Ecclesiastica, VII, 13; Jones, Arnold Hugh Martin, John Robert Martindale, John Morris, The Prosopography og the Later Roman Empire, vol. 2, Cambridge University Press 1992, 316.

35 Norman Wood, The Cambridge Ancient History, Vol. XIII, The Late Empire, A.D. 337-425, Cambridge University Press, 2008, 516-537.

${ }^{36}$ R. C. Blockley, CAH, 120-126.
} 
Valentinijan II nije imao posebnih uspeha ni posle vraćanja na tron. Umro je 15. maja 392. godine. Nakon toga, 22. avgusta, u Rimu se pojavio novi avgust, Flavije Eugenije, koga su proglasile i podržale legije sastavljene od Germana, i nekadašnji Valentinijanov savetnik i vojskovođa - Argobast, poreklom Franak. ${ }^{37}$

Teodosije se nije pomirio sa ovim izborom i već u januaru 393. godine proglasio je svog sina Honorija za novog avgusta na Zapadu. Skupljajući pristalice za sukob sa Teodosijem, Eugenije je pokušao da još jednom, po poslednji put u istoriji Rima, obnovi stare kultove i verovanja. ${ }^{38}$ Ipak, njegov poraz u bici kod reke Frigida, 6. septembra 394. godine, označio je i konačnu pobedu hrišćanstva nad paganskim verovanjima u Rimskom carstvu.

Posle pobede nad Eugenijem, Teodosije je došao u Milano, ali se tu ubrzo razboleo i umro, 17. januara 395. godine. Njegovom smrću naslednici Carstva su postali njegovi sinovi - Arkadije $^{39}$ i Honorije. $^{40}$ Njihova vladavina preobraziće Rimsko carstvo iz jedinstvene države u dva entiteta - Istočno i Zapadno rimsko carstvo. Samim tim jača i uloga administracije, tačnije, carevi se okružuju savetnicima i vojskovođama koji formiraju svojevrsnu vladu, te se i time doprinosi razdvajanju dva dela carstva. Javljaju se i borbe oko prestola, koje više nisu vezane samo za titulu cara. Vojska, kao i njeni generali, sve manje ostaju rimski, a sve više postaju germanski ili gotski - u zavisnosti od toga gde su jedinice locirane. Isto tako, pojedine varvarske vojskovođe, u svojstvu rimskih generala, postaju sve zahtevnije i agresivnije u odnosu prema carevima. Ni Istočno ni Zapadno rimsko carstvo neće biti u stanju da reše ovaj problem, tako da će 5 . vek nove ere, posle niza udaraca, označiti i konačnu propast Zapadnog rimskog carstva. ${ }^{41}$

Sedamnaestogodišnji Arkadije, posle smrti oca, preuzeo je upravu nad istočnim delom Rimskog carstva, iako je titulu avgusta nosio još od 383. godine. Njegov brat, Honorije, nasledio je Zapad, ali je takođe titulu avgusta nosio odranije - od 393. godine. Kako zbog Arkadijeve mladosti tako i zbog njegove nesposobnosti da se uhvati u koštac s problemima, ulogu vladara je praktično vršio njegov savetnik i prefekt pretorija Rufin, ${ }^{42}$ poreklom Gal. S druge strane, Honorije je takođe imao savetnika koji je preuzeo ulogu zaštitnika cara i, zapravo, upravljao njegovim delom Carstva. To je bio Vandal Stilihon, ${ }^{43}$ bračnim vezama povezan sa Teodosijevom porodicom, koji je pretendovao da bude zaštitnik oba mlada cara. Savetnici careva, Rufin i Stilihon, nisu gajili međusobno poštovanje, što se odrazilo i na poslove Carstva, a s druge strane, vodili su neprestanu bitku da očuvaju svoje sopstvene pozicije na dvoru.

Rufinu je to bilo daleko teže, jer je njegovu ulogu želeo dvorski službenik Eutropije, a zatim i carica Eudoksija, čiji je otac bio uticajni franački general. Ona je,

\footnotetext{
${ }^{37}$ B. Croke, Arbogast and the Death of Valentinian II, Historia 25 (2), 1976, 235-144.

${ }^{38}$ Ponovo je smeštena u Senat statua Pobede, koja je uklonjena po Gracijanovom naređenju, i obeleženi su tradicionalni praznici.

${ }^{39}$ Zosimus, V; John Bagnall Bury, History of the Later Roman Empire, New York 1958, 213.

${ }^{40}$ A. Cameron, J. Lang, Barbarians and Politics at the Court of Arcadius, Berkeley-Oxford 1993.

${ }^{41}$ R. C. Blockley, $C A H, 429-433$.

${ }^{42}$ Zosimus, IV, 51.

${ }^{43}$ S. Mazzarino, Stilicone, Roma 1942; P. G. Christiansen, The use of images by Claudius Claudianus, The Hague

- Paris 1969, 16-27.
} 
posle stupanja u brak sa Arkadijem, imala sve veći uticaj na cara. Njegova karijera je okončana 395. godine: ubili su ga legionari koji su se vratili sa zapada da pomognu da se uguši nezadovoljstvo Vizigota predvođenih Alarihom, kao i da se zaustave hunski upadi u Malu Aziju. Ovaj događaj usledio je nakon što je Stilihon krenuo sa kombinovanim istočnim i zapadnim legijama u pomoć caru Arkadiju (istočne legije su u Italiju došle sa Teodosijem), ovaj pohod obustavljen je na Arkadijev zahtev, a Stilihon je morao istočne legije, umesto da ih angažuje u borbi sa Alarihom, uputi u Konstantinopolj. ${ }^{44}$

Ovi prvi pokazatelji nesloge između dva cara, tj. njihovih savetnika, išli su u korist Vizigotima koje je predvodio Alarih. Iako u statusu rimskih federata, oni su se pobunili i počeli da pljačkaju Epir i Tesaliju. Stilihon je 397. godine ponovo krenuo u pohod protiv Alariha, ali je i ovaj put izbegnut odlučan sukob: iako su Goti morali da se povuku, njihova snaga ostala je nenarušena. ${ }^{45}$ To je dovelo do toga da, sledeće godine, Arkadije i zvanično preda Alarihu na upravu provinciju Iliriju, i da ga vojno uzdigne, u pokušaju da zadovolji apetite gotskog vojskovođe. Za ovu prinudnu odluku Istok je krivio Stilihona, koji je čak proglašen neprijteljem istočnog dela carstva. Nesporazumi, pa čak i otvoreni sukobi, nastavljeni su 398. godine, u provinciji Africi, koju je Gildon pokušao da otcepi od zapadnog dela i pripoji istočnom delu Carstva, ali mu to nije pošlo za rukom. Previranja u istočnom delu carstva su nastavljena, a za političke borbe na dvoru su korišćeni i nerešeni problemi sa upadima Huna, odnosno sa pobunom Ostrogota, koji su bili u svojstvu federata. Rezultat ovih borbi je Eutropijeva smrt i konačna prevlast carice Eudoksije. $^{46}$

Sam početak 5. veka, doneo je nove probleme sa Alarihom i Vizigotima, koji su samo čekali izgovor da nastave sa svojim pohodima protiv jednog ili drugog dela Carstva. Pošto je veći deo Balkana već bio opljačkan, 401. godine Alarih je odlučio da krene na Italiju i, verovatno, na Galiju. Međutim, 402. godine Stilihon ga je zaustavio u bici kod Polencije i naterao na povlačenje. Stilihon, međutim, nije imao snage da dokrajči neprijatelja, jer su i njegove trupe bile pretežno sastavljene od federata, koji nisu uvek pokazivali željenu disciplinu. Iako na trenutak siguran od napada, zapadni deo carstva je sve više morao da brine o odbrani same Italije. U tu svrhu povlačene su legije sa Rajne i iz Britanije, čime su te provincije ostale otvorene za upade drugih varvarskih plemena. Čak ni sa tim snagama, ni sa plaćeničkim odredima Huna i Alana, Stilihon nije mogao da zaustavi invaziju Ostrogota na sever Italije, tokom 405. godine. Sve dok se, kao i većina varvarskih plemena u potrazi za plenom, Ostrogoti nisu razdvojili na više manjih grupa, sever Italije je, praktično, bio u njihovim rukama. Ipak, sačekavši da se podele, Stilihon ih je potukao i ponovo uspostavio vlast nad ovim delom zemlje. ${ }^{47}$

Radost zbog pobede kratko je trajala, jer je već prvog dana 406. godine na Zapadu došlo do pojave novog, ozbiljnijeg problema. Vandali, Alani, a za njima i Burgunđani i Alemani provalili su u provinciju Germaniju i Galiju, i praktično ih

\footnotetext{
${ }^{44}$ John Curran, $C A H, 104-108$.

${ }^{45}$ Emma Burrell, A Re-Examination of Why Stilicho Abandoned His Pursuit of Alaric in 397, Historia 53 (2), 2004, 251-256.

${ }^{46}$ Upor. Г.Острогорски, Историја Византије, 70-80; Ф.Успенски, Историја Византијског иарства, 132-153.

${ }^{47}$ Ibidem.
} 
preplavili. Vandali i Alani su došli čak do Pirineja. Franački federati, kao i druge galoromanske snage, nisu mogli da zaustave ovu bujicu naroda koja se sručila na granice. Istovremeno, u Britaniji su izbili nemiri, i pojavila su se tri uzurpatora, od kojih je poslednji, Konstantin, 407. godine čak poveo vojsku protiv Honorija. Time su sprečeni Stilihonovi planovi da uz Alarihovu pomoć pripoji Iliriju zapadnom delu carstva. Poslavši veći deo vojske na zapad, Honorije je uspeo da zaustavi napad uzurpatora (ne i da ga dotuče), ali je sada Alarih tražio odštetu zbog neispunjenog obećanja. Iako je Stilihon bio za ispunjenje ovog zahteva, dvor je odlučio drugačije i Alarih je dobio novi izgovor za pohod na Italiju.

Posle relativnog zatišja na Istoku, Arkadijevom smrću, 408. godine, postavilo se pitanje nasledstva. Postoje sumnje da je Stilihon želeo da na to mesto dovede svog sina, dok je car Honorije bio zagovornik toga da se na presto istočnog dela popne mladi Teodosije II, njegov sinovac. Sukob između cara i Stilihona završio se porazom slavnog vojskovođe. Stilihon je na kraju i ubijen, a Teodosije II $^{48}$ je postao car istočnog dela Rimskog carstva. Iskoristivši Silihonovu smrt, Alarih je 408. godine ponovio napad na Italiju i stigao do samog Rima. Tada je Rim pristao da isplati ogroman otkup Vizigotima i Alarih je prestao sa opsadom. Posle Honorijeve intervencije Alarih je čak pristao da u budućnosti sarađuje sa njim - jer su se usled nove pobune u Africi javili problemi sa isporukom žita. Italiji i Vizigotima zapretila je glad. Diplomatska saradnja ipak nije zaživela, jer su obe strane tražile način i izgovor da se reše one druge. Tako je Alarih 410. godine taj izgovor dobio u napadu na svog zeta, za koji je okrivio cara, i ponovo je opseo Rim. Ovaj put opsada je trajala kratko i 24. avgusta 410. godine Vizigoti su ušli u drevni grad i tokom tri dana u potpunosti ga opljačkali. Vizigoti su posle toga krenuli na carsku prestonicu, Ravenu, ali se Alarih razboleo i umro. Njegov naslednik, Ataluf, odlučio je da Vizigote izvede iz Italije i oni su prešli u Galiju, a zatim se nastanili na području južno i severno od Pirineja. ${ }^{49}$

I narednih godina nastavljene su bitke, pošto je Honorije morao da se obračuna sa uzurpatorima Konstantinom, a zatim i Jovinom. Varvarska plemena, ali i federati i rimske legije često su menjali saveznike. Razultat svih tih borbi bio je da je Honorije sačuvao presto (uspevši da do 413. godine pobedi sve pretendente), ali i da su Britanija, Galija, kao i Pirinejsko poluostrvo, postali dom varvarskih plemena koji su tu uspostavili svoje kraljevine. Ta plemena će sarađivati ili ratovati sa Rimom i u narednim decenijama, a Zapadno rimsko carstvo će na kraju biti svedeno samo na Italiju i delove provincije Ilirije. Bez vojne i ekonomske snage da se suprotstavi varvarima, Rim će se sve više oslanjati na federate, plaćeničku vojsku i na saveze sa pojedinim plemenima. Rezultat takve politike je poznat, i 476. godine, dovešće do konačnog pada Zapadnog rimskog carstva, tj. do svrgavanja poslednjeg rimskog cara. ${ }^{50}$ To je učinio Odoakar, vođa germanskih najamnika.

\footnotetext{
48 J. B. Bury, History of the Later Roman Empire vol. 1, 271ss.

${ }^{49}$ R. C. Blockley, CAH, 429-433.

${ }^{50}$ 475. godine rimski patricije Orest doveo je na presto svog sina Romula Augustula i u njegovo ime upravljao državom. Ali, protiv njega su se pobunili varvarski najamnici, na čijem se čelu nalazio jedan Skit, Odoakar. Orest je 476. godine bio ubijen, Romul Augustul svrgnut sa vlasti, a znake carskog dostojanstva Odoakar je poslao u Konstantinopolj. Uobičajeno je da se ovaj događaj smatra krajem Zapadnog rimskog carstva. Vid. Cassiodorus, Variae epistulae, III, 35.
} 
Izvori i literatura:

Agathias, The Histories (translated with an interdiction and short explainary notes by Joseph D. Frendo), Berlin - New York 1975.

Амијан Марцелин, Историја (предговор, превод и објашњења Милена Милин), Београд 1998.

Blockley, R. C., The Cambridge Ancient History, Vol. XIII, The Late Empire, A. D. 337-425, Cambridge University Press, 2008.

Burrell, E., A Re-Examination of Why Stilicho Abandoned His Pursuit of Alaric in 397, Historia:

Zeitschrift für Alte Geschichte. Band 53, (2), 2004.

Bury, J. B., History of the Later Roman Empire, I, London 1923.

Cameron, A., Lang, J., Barbarians and Politics at the Court of Arcadius, Berkeley-Oxford 1993.

Cameron, A., Garnsey P., The Cambridge Ancient History, Vol. XIII, The Late Empire, A.D. 337-425, Cambridge University Press, 2008.

Christiansen, P. G., The use of images by Claudius Claudianus, Mouton, The Hague - Paris 1969.

Codex Theodosianus, A Dictionary of Greek and Roman Antiquities (ed. John Murrey), London 1875.

Croke, B., Arbogast and the Death of Valentinian II, Historia: Zeitschrift für Alte Geschichte. Band 25 (2), 1976, 235-144.

Curran, J., The Cambridge Ancient History, Vol. XIII, The Late Empire, A.D. 337-425, Cambridge University Press, 2008.

Demandt, A., Die Spätantike. Römische Geschichte von Diocletian bis Justinian 284-565 n.Chr., München 1989.

Eusebius Pamphilius, Church History, Life of Constantine, Oration in Praise of Constantine, Wm. B. Eerdmans, 1979.

Eutropius, Brevarium (translated with an introduction and commentary by H. W. Bird), Liverpool University Press, 1993.

Fowden, G., The Cambridge Ancient History, Vol. XIII, The Late Empire, A.D. 337-425, Cambridge University Press, 2008.

Gibbon, E., The Decline and Fall of the Roman Empire, II, New York, 1969 (prvo izdanje 1776).

Heather, P., The Cambridge Ancient History, Vol. XIII, The Late Empire, A.D. 337-425, Cambridge University Press, 2008.

Hunt, D., The Cambridge Ancient History, Vol. XIII, The Late Empire, A.D. 337-425, Cambridge University Press, 2008.

Kelly, C., The Cambridge Ancient History, Vol. XIII, The Late Empire, A.D. 337-425, Cambridge University Press, 2008.

Lactantius, The Divine Institutes, Books 1-7 (translation by William Fletcher, in A. Roberts and J. Donaldson eds.), Edinburg 1994.

Libanii OPERA (recensuit Richardus Foerster), Lipsiae 1903.

Машкин, Х. А., Историја старог Рима, Београд 1982.

Mazzarino, S., Stilicone, Roma 1942.

Острогорски, Г., Историја Византије, Просвета, Београд 1996.

Sozomen, Ecclesiastical history. A history of the Church in nine books, from A.D. 324 to A.D. 440 by Hermias Sozomenus, London 1846.

Stein, E., Geschichte des spätrömischen Reiches I: vom römischen zum byzantinischen Staate (284-476 n. Ch.), Wien 1928.

Успенски, Ф., Историја Византијског изарства (превео Зоран Буљугић), Београд 2000.

Wood, N., The Cambridge Ancient History, Vol. XIII, The Late Empire, A.D. 337-425, Cambridge University Press, 2008.

Wright, W. C., The Works of the Emperor Julian, 3 Volumes, Harvard University Press, 1913 (1980). 
Zonaras, The History of Zonaras, from Alexander Severus to the Death of Theodosius the Great (translated by Thomas Banchich, Eugene Lane; introduction and commentary by Thomas M. Banchich), Rutledge 2009.

Zosimus, New History (Byzantina Australiensia 2) (translated R. T. Ridley), London, 1982. 


\title{
ONE BRIEF OVERVIEW \\ OF POLITICAL CIRCUMSTANCES IN THE ROMAN EMPIRE DURING THE FOURTH AND FIFTH CENTURIES
}

\begin{abstract}
Summary
In the latter half of the fourth century, Rome entered its final phase of existence as a unified empire and great military, economic and cultural power. Problems which had been gathering for years throughout the empire culminated in this period, leading over the next few decades to the fall of the Western Roman Empire and the beginning of a new era, the Middle Ages. This work seeks to expand the historical picture with new findings regarding the late Roman Empire.
\end{abstract}

Keywords: Roman Empire, Constantius II, Julian, Jovian, Valentian, Valens, Gratian, Valentian II, Goths, Persians, Huns, Theodosius, Magnus Maximus, Eugenius, Honorius, Arcadius, Stilicho, Rufinus. 